\title{
Fifty consecutive pancreatectomies without mortality
}

\section{Cinquenta pancreatectomias consecutivas sem mortalidade}

\author{
Enio Campos Amico 1,2,3; Élio José Silveira da Silva Barreto 1,3; José Roberto Alves 1,2,3; Samir Assi João 1,3; Priscila luana Franco \\ Costa Guimarães²; Joafran Alexandre Costa de Medeiros ${ }^{1}$
}

\section{A B S T R A C T}

\begin{abstract}
Objective: to report the group's experience with a series of patients undergoing pancreatic resection presenting null mortality rates. Methods: we prospectively studied 50 consecutive patients undergoing pancreatic resections for periampullary or pancreatic diseases. Main local complications were defined according to international criteria. In-hospital mortality was defined as death occurring in the first 90 postoperative days. Results: patients' age ranged between 16 and 90 years (average: 53.3). We found anemia $(\mathrm{Hb}<12 \mathrm{~g} / \mathrm{dl})$ and preoperative jaundice in $38 \%$ and $40 \%$ of cases, respectively. Most patients presented with peri-ampullary tumors (66\%). The most common surgical procedure was the Kausch-Whipple operation (70\%). Six patients (12\%) needed to undergo resection of a segment of the mesenteric-portal axis. The mean operative time was 445.1 minutes. Twenty two patients (44\%) showed no clinical complications and presented mean hospital stay of 10.3 days. The most frequent complications were pancreatic fistula (56\%), delayed gastric emptying $(17.1 \%)$ and bleeding (16\%). Conclusion: within the last three decades, pancreatic resection is still considered a challenge, especially outside large specialized centers. Nevertheless, even in our country (Brazil), teams seasoned in such procedure can reach low mortality rates.
\end{abstract}

Key words: Pancreas. Surgical Procedures, Operative. Pancreatectomy. Pancreaticoduodenectomy. Mortality.

\section{INTRODUCTION}

P ancreatic resection is still a complex procedure. Although described in the first half of the twentieth century, the cephalic resection of the pancreas was infrequently practiced because of poor early results ${ }^{1}$. Until the 70 s, mortality rates were high, even in North America ${ }^{1}$. Mortality of around $25 \%$ with pancreaticoduodenectomy was frequent, which raised doubts about the implementation of this operation in the treatment of pancreas adenocarcinoma ${ }^{1}$. It was not until the 60s, with a pioneer creation of specialized services for the treatment of pancreatic diseases, that the John Hopkins Hospital in Baltimore, under the leadership of John Cameron, achieved better results ${ }^{2}$. Currently, in major centers the procedure is routinely performed; its indications for some pre-malignant diseases, or even benign ones, have become accepted; the length of stay has become smaller; and, above all, the mortality rate has become less than $3 \%^{3}$.

This study presents a series of consecutive cases of pancreatic resections with no mortality. We discuss aspects related to preoperative preparation, surgical technique and postoperative care.

\section{METHODS}

This study was approved by the Ethics in Research Committee of the hospitals where surgical procedures were performed: Hospital Universitário Onofre Lopes, Liga Norte Riograndense Contra o Câncer and Casa de Saúde São Lucas, Natal, RN, Brasil; the number in Brazil Platform was 04198212.6.0000.5292.

We prospectively analyzed 50 consecutive patients undergoing pancreatic resections, from June 2010 to November 2013, for the treatment of peri-ampullary or pancreatic diseases.

Preoperatively, patients over 60 years of age or with cardiovascular risk factors regardless of age underwent cardiac tests to identify coronary artery disease and heart failure. Nutritional assessment was performed in all patients. For severe malnutrition, we indicated preoperative enteral nutritional support for a period not less than 15 days. We did not indicate endoscopic prosthesis preoperatively in patients with obstruction of the bile duct unless we foresaw a prolonged preoperative preparation or in the presence of cholangitis.

The technical steps of the two main types of operation carried out are described in a previous

1. Hospital Universitário Onofre Lopes, Universidade Federal do Rio Grande do Norte. Natal, RN, Brasil; 2. Liga Norte Riograndense Contra o Câncer. Natal, RN, Brasil; 3. Hospital Casa de Saúde São Lucas. Natal, RN, Brasil. 
publication ${ }^{4}$. While in the first half of the series to a termino-terminal invaginating pancreato-jejunal anastomosis had been preferred, from the 25th case on we chose the termino-lateral invaginating pancreatojejunal anastomosis in a single plan with separate stitches (5.0 prolene), for cases of pancreas with softened texture and/or main pancreatic duct with normal or decreased caliber. In operations of Kausch-Whipple (gastroduodenopancreatectomy without preservation of the pylorus) and central pancreatectomies, we used two silicone laminar drains externalized one on each side. In body and tail pacreatectomies, we used a silicon single laminar drain exteriorized in the left flank. A routine Witzel's jejunostomy was made independently of the type of procedure.

In the immediate postoperative period until the first 48 hours of operation, we used liberal fluid replacement, consisting of intravenous infusion of crystalloids, preferably Ringer Lactate solution (60ml/kg/day) combined with $30 \mathrm{~g} /$ day of human albumin. A basic monitoring through continuous and serial measurement of central venous pressure, urine output, blood gases and serum lactate, served to guide hydration adjustments.

For prophylaxis of pancreatic fistula, in most patients we used octreotide subcutaneously, depending on the hospital availability, at a dose of $0.3 \mathrm{mg} /$ day, in eighthour intervals for seven days. We daily recorded the drains debt and held dosages of in the fluid in the first, third, fifth and seventh days after surgery. In the last 15 cases, we also measured amylase of the fluid drains on the ninth day after surgery.

In most cases, on the seventh day after surgery, we carried out a control ultrasound or CT study; we then removed the drains on the eighth day after surgery for cases with low amylase on the fluid drains (less than three times the upper limit of normal serum amylase) and imaging exam without abdominal collections. In the last 15 patients we delayed in two days the imaging exam and drains removal. In the presence of pancreatic fistula, the patient was kept in zero oral intake, with enteral nutrition introduced via jejunostomy and the subcutaneous octreotide was maintained. In the presence of abdominal abscesses, we instituted antibiotic therapy and proceeded to percutaneous drainage of the collection. In case of persistent septic focus, we carried out a reopearation for drainage of the collections. In the absence of abdominal collections and high level of drain fluid amylase in the ninth day after surgery, the patient was discharged.

For the diagnosis of pancreatic fistula, we used the criteria of the International Study Group on the Definition of Pancreatic Fistula (GIEDFP) ${ }^{5}$, and for the diagnosis of bleeding and delayed postoperative gastric emptying, the criteria of the International Study Group of Pancreatic surgery $(\mathrm{GIECP})^{6,7}$

We defined in-hospital mortality as death occurred within the first 90 days postoperatively.

\section{RESULTS}

Fifty patients consecutively underwent some type of pancreatic resection. Adenocarcinoma of the duodenal papilla was the most frequent disease (Table 1). The ages ranged between 16 and 90 years (mean $=53.5$ ) and the majority were male $(42 \%)$. Anemia $(\mathrm{Hb}<12 \mathrm{~g} / \mathrm{dl})$ and jaundice were part of the initial clinical presentation, respectively, in $38 \%$ and $40 \%$ of patients.

Two patients were preoperatively diagnosed with significant coronary disease. In one operation was postponed after implantation of coronary prosthesis and on the other, pancreatic surgery was contraindicated, since there was triple vessel coronary artery disease, with CABG indication. The recognition of severe malnutrition after nutritional assessment also delayed surgical treatment in at least seven patients in the series.

The Kausch-Whipple procedure was the most common (Table 2). There was need for red blood cell transfusion in 19 patients (39.5\%).

In six patients (12\%) there was need for resection if a mesenteric-portal axis segment. Mean operative time was 445.1 minutes (165-720).

When excluding grade A pancreatic fistulas, 22 patients (44\%) had no clinical complications and had an average length of stay of 10.3 days. The remaining displayed one or more complications (Table 3).

Six patients had late pancreatic fistula ( $>8$ days). In four of these patients, the drain was still present and the diagnosis was made by low amylase values until the seventh day after surgery and their increase after the ninth day. In the other two cases, the drains had been removed and the patients had infected abdominal collection with high amylase values. In one such case the collection was punctured, guided by $\mathrm{CT}$, and in the other case where there was no window for percutaneous drainage, a chest

Table 1 - Distribution of diseases.

\begin{tabular}{lc}
\hline Disease & N \\
\hline Adenocarcinoma of the duodenal papilla & 19 \\
Adenocarcinoma of the pancreas & 12 \\
Frantz tumor & 6 \\
Serous cystadenoma & 3 \\
Focal chronic pancreatitis & 3 \\
Neuroendocrine tumor & 2 \\
Cholangiocarcinoma & 1 \\
Adenocarcinoma of the duodenum & 1 \\
Adenoma of the duodenum & 1 \\
Mucinous cystadenoma & 1 \\
Insulinoma & 1 \\
TOTAL & 50 \\
\hline
\end{tabular}

Source: Medical records of patients undergoing pancreatic resections (June / 2010-November / 2013). 
Table 2 - Distribution of types of pancreatic resections.

\begin{tabular}{|c|c|c|}
\hline Procedures & Incid & nce $(\%)$ \\
\hline Kausch-Whipple & 35 & $(70 \%)$ \\
\hline Body-tail pancreatectomy with splenectomy & 5 & $(10 \%)$ \\
\hline Central pancreatectomy & 4 & $(8 \%)$ \\
\hline Body-tail pancreatectomy with laparoscopic splenectomy & 3 & $(6 \%)$ \\
\hline Enucleation & 2 & $(4 \%)$ \\
\hline Uncinectomy & 1 & $(2 \%)$ \\
\hline Total & 50 & $100 \%)$ \\
\hline
\end{tabular}

Source: Medical records of patients undergoing pancreatic resections (June / 2010-November / 2013).

tube was inserted by the previous surgery drain orifice (Figure 1). These were the only two cases of readmission due to complications related to the surgical procedure $(4 \%)$.

\section{DISCUSSION}

In Brazil, few publications are devoted to the overall results of pancreatectomy performed for various diseases in the same service or the same group of surgeons.

In general, mortality rates found in national publications by the year 2012 ranged between $4.3 \%$ and $21.9 \%^{8-14}$, being superior to those described in the international literature ${ }^{3}$.

Table 3 - Distribution of identified postoperative complications.

\begin{tabular}{|c|c|}
\hline Complications & Incidence (\%) \\
\hline Pancreatic fistula & $28(56 \%)$ \\
\hline Grade A & $11(22 \%)$ \\
\hline Grade B & $13(26 \%)$ \\
\hline Grade C & $4 \quad(8 \%)$ \\
\hline $\begin{array}{l}\text { Delayed Gastric Emptying } \\
\text { (Just after the Kausch-Whipple operation) }\end{array}$ & $6(17.1 \%)$ \\
\hline Grade A & $2(5.7 \%)$ \\
\hline Grade B & $3(8.6 \%)$ \\
\hline Grade C & $1(2.8 \%)$ \\
\hline Bleeding & $8(16 \%)$ \\
\hline Grade A & $3 \quad(6 \%)$ \\
\hline Grade B & $1 \quad(2 \%)$ \\
\hline Grade C & $4 \quad(8 \%)$ \\
\hline Intra-abdominal collection & $5(10 \%)$ \\
\hline Biliary fistula & $3 \quad(6 \%)$ \\
\hline Renal insufficiency & $2 \quad(4 \%)$ \\
\hline Wound infection & $1 \quad(2 \%)$ \\
\hline
\end{tabular}

Source: Medical records of patients undergoing pancreatic resections (June / 2010-November / 2013).

Note: When excluding the Grade A pancreatic fistulae, twenty eight patients (56\%) developed one or more concurrent complications presented in this table.
Two recent national studies should be highlighted due to their excellent results.

In the first, Machado et al. reported a significant number of patients undergoing laparoscopic pancreatectomy, with zero mortality ${ }^{15}$. These authors described their personal experience in 11 years with the most diverse types of pancreatic resection, ranging from enucleation to pancreaticoduodenectomy. Most procedures (91.6\%) were performed by completely laparoscopic technique, the conversion rate was only $3.1 \%$, and the rate of pancreatic fistula, $28.1 \%{ }^{15}$. Although one can notice a progressive increase in the complexity of procedures over time, most cases were operated on due to benign disease and subjected to resection of body and tail of pancreas, reflecting a

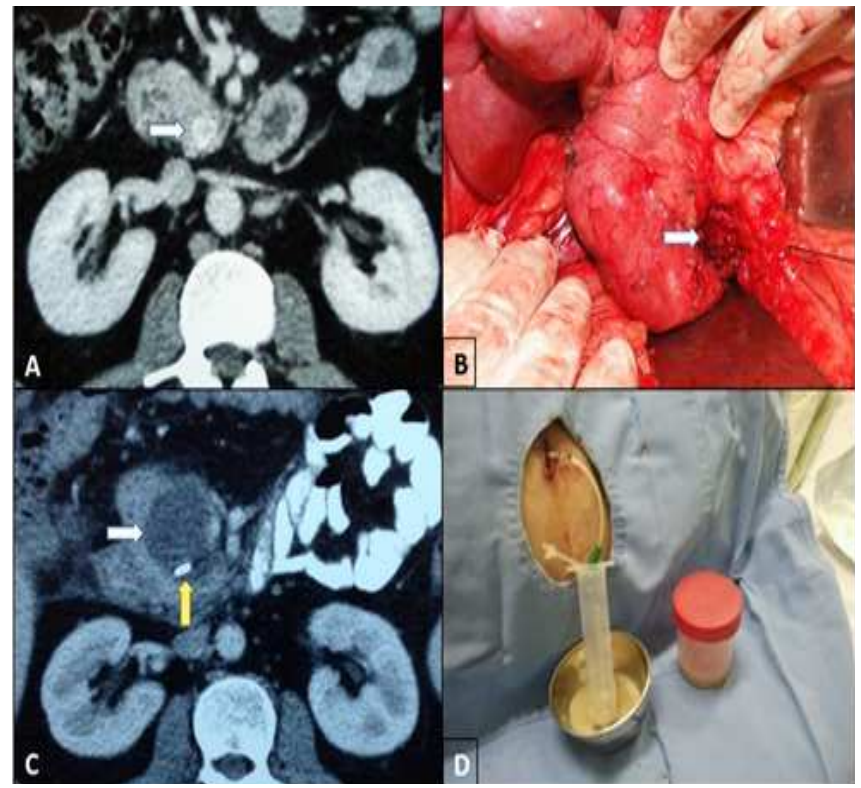

Figure 1 - A) Computerized tomography showing vascular lesion in the pancreas uncinate process. B) Intraoperative aspect: enucleation of insulinoma. C) postoperative collection of surgical site and surgical clip. D) Abscess drainage: chest tube inserted through the drain orifice. 
selection of less complex cases justified for the application of the laparoscopic approach.

The other study ${ }^{16}$, although including only patients undergoing pancreaticoduodenectomy, put greater resemblance to the current series. In it, Fontes et al. performed a retrospective analysis of 97 patients over 12 years in the Hepato-bilio-pancreatic Surgery Service of the University of Medical Sciences of Porto Alegre ${ }^{16}$. In this study, the average hospital stay was 15 days, the fistula rate of pancreatic clinic, $10.3 \%$, and the mortality rate, $2.1 \%{ }^{16}$.

The number of cases presented in this study consisted essentially of unselected patients from the point of view of their disease, seen mostly in a tertiary public service reference for complex diseases of the pancreas. At least $1 / 3$ of the patients found itself weakened, with jaundice and anemia. Malignancy was the main indication for operation in 41 patients (82\%). The mostly performed procedure was the Kausch-Whipple surgery $(70 \%$ of cases), and in $12 \%$ of cases there was the need to resect any portion of the mesenteric-portal axis. Although this series is small and we recognize that the death rate alone does not necessarily reflect overall treatment quality, especially in patients undergoing cancer surgery, our immediate results may be comparable to those of large referral services in pancreatic surgery 2,17 .

Luft et al., in 1979, were the first to relate surgical procedures of high complexity and hospital volume with lower mortality rates ${ }^{18}$. In an important publication in the New England Journal of Medicine, in 2002, Birkmeyer et al. analyzed the results of 2.5 million patients undergoing cardiac procedures and cancer surgery between 1994 and 1999, and observed mortality rates after pancreatectomy in patients operated on at low volume hospitals compared with those treated in high volume ones, respectively, of $16.2 \%$ and $3.8 \%{ }^{19}$. The next year, the same authors assessed the individual volume of each surgeon and found a mortality rate three times higher for surgeons who had performed less than two pancreatectomies a year ${ }^{20}$.

Even when different surgeons operate in the same service, one can find different results. Tseng et al. reported a "learning curve" for pancreatectomy from a sample with surgeons at MD Anderson Cancer Center ${ }^{21}$. The results relating to blood loss, operative time and length of stay were better for surgeons who had performed more than 60 procedures ${ }^{21}$. From these publications, regionalization to highly complex surgery has been recommended, although with conflicting results in the United States and Europe ${ }^{22}$.

Our experience with pancreatic resection began in 2002 and we have held 84 surgeries so far. In the first 34 cases, mortality was $11.7 \%$, compared with zero mortality rate obtained in the last 50 cases. This allows us to recognize that we lived a real terms "learning curve". Based on this experience, we updated our routines protocol, which is now applied in all hospitals where we perform the procedure, which includes a thorough preoperative evaluation, with particular emphasis on improvement of preoperative nutritional status, a standardized operative tactical technique and with little blood loss, and strict postoperative control, recognizing and treating early complications when present, especially pancreatic fistulas.

Recently there has been much emphasis in the literature the concern in establishing strategies to reduce the stress of surgical procedures and maintain body homeostasis. Widely described for colectomy, the fast-track programs have also been applied for pancreatic surgery. Thus, Berberat et al. ${ }^{8}$, Balzano et al. ${ }^{23}$ and di Sebastiano et al. ${ }^{24}$ found an average hospital stay of 10,13 and 10 days, respectively, in series of patients undergoing pancreatectomy. Postoperative fluid restriction, early oral intake and mobilization, effective analgesia and early removal of drains and catheters form, in general, the main recommendations suggested by these and other authors ${ }^{8,23-}$ ${ }^{25}$. While we agree with most of these measures, we do not practice fluid restriction, neither the early removal of abdominal drains.

The perioperative excess in fluids administration is implicated in the increased rate of complications and delay in return of intestinal transit in colorectal surgery ${ }^{26}$. For pancreatic surgery, however, there is insufficient data. In a recent publication, Grant et al. retrospectively studied 1,030 patients undergoing pancreatic resection and were unable to find any correlation between the amount of administered liquid and postoperative complications ${ }^{27}$. We do not deem reasonable to compare the third space volume formed in the operated area after pancreatic resection with the ones formed after other digestive procedures. The dissection area of the Kausch-Whipple operation is larger, and so is the third space, the restrictive fluid infusion being unable to maintain an adequate effective blood volume. We clearly recognized this fact in the first part of our series, when we had a more restrictive policy for the administration of crystalloid solutions in pancreatectomy intra- and postoperative periods, particularly in cephalic pancreatic resections. In such circumstances, oliguria was common, and we even had two cases of postoperative acute renal failure. From these cases, we initiated a liberal policy for volume replacement with crystalloid and colloid solutions. Postoperative acute renal failure requiring dialysis seems more deleterious than fluid overload that may subsequently develop due to more liberal fluid infusion in patients with previously appropriate renal or cardiac function.

Early removal of abdominal drains and even nonuse in pancreatic resection surgery has been widely recommended ${ }^{28-30}$. Contrary to this trend, a recent multicenter study at nine US academic centers with a high volume of surgeries in which they randomized the use or not of abdominal drain after pancreaticoduodenectomy concluded for the lack of safety in the abolition of the drain after the procedure ${ }^{31}$. The mortality rate was four times higher $(12 \%$ vs. $3 \%)$ in cases where the drain was not used, which led to discontinuation of the study ${ }^{31}$. We agree 
with the practice of routinely using the abdominal drain in pancreatectomies. Our current policy is the routine use of two abdominal drains (in cephalic resections) and not remove them before the ninth day after surgery, at which time we make the last dosage of amylase and imaging exam. This approach is justified for the following reasons: 1) late pancreatic fistulas are not uncommon; 2) professional that percutaneously drain abdominal collections are not available at any time, especially in public hospitals; 3 ) once the collection is diagnosed, there is not always a window for percutaneous drainage and further surgery may be required; and 4) the presence of the drain does not prevent discharge, especially in pancreatic resections of body and tail of the pancreas.

Although the early removal of drains may be related to a reduction in length of stay, particularly in cephalic resections, we are convinced that the most important factor is, in fact, the development or absence of complications, particularly pancreatic fistula. This can be seen by the average length of stay of 10.3 days obtained with our patients without any clinical complications. The cost of maintaining the patient hospitalized for two days is not high because the patient without complication on the eighth day after surgery is already feeding, ambulating without intravenous access and with appropriate, oral drug pain control. Conversely, patients who develop pancreatic fistula have longer hospital stay depending on the fistula characteristics. For this group we prefer that the drain placed during surgery is still in place, which guarantees, in most patients, the proper treatment of the fistula, combined with enteral nutrition by the jejunostomy.

For the accounting of our clinical complication rate, we excluded Grade A pancreatic fistulae, essentially because it is a laboratory diagnosis without any implication on the patient's clinical, which can be observed in our patients ${ }^{32}$. Although we measured the amylase value on the third day after surgery for the diagnosis of fistula in accordance with the GIEDFP criteria ${ }^{5}$, we consider of much greater practical importance the amylase measurements of the seventh and ninth postoperative days. Although not the subject of this study, apparently amylase levels increased in this period were much more correlated with the clinical development of fistula and prolonged hospitalization.

Despite major advances over the past three decades, pancreatic resection is still considered a challenge, especially outside the major specialized centers. Nevertheless, a low or nil mortality rate is possible. With practice, one accumulates knowledge about the disease and surgical treatment, allowing patients to be better prepared, the technical steps of the surgery to become standardized and easier, and postoperative complications to be more clearly recognized and properly treated.

\title{
RE S U M O
}

\begin{abstract}
Objetivo: apresentar uma série de casos consecutivos de ressecções pancreáticas com mortalidade nula, discutindo os aspectos relacionados ao preparo pré-operatório, técnica cirúrgica e cuidados pós-operatórios. Métodos: foram analisados prospectivamente 50 pacientes consecutivos submetidos à ressecções pancreáticas para o tratamento de doenças pancreáticas ou periampulares. As principais complicações locais foram definidas segundo critérios internacionais. A mortalidade intra-hospitalar foi considerada quando o óbito ocorreu nos primeiros 90 dias do pós-operatório. Resultados: a faixa etária variou entre 16 e 90 anos (média: 53,3 anos). Anemia $(H b<12 \mathrm{~g} / \mathrm{dl})$ e icterícia pré-operatória estavam presentes, respectivamente, em $38 \%$ e $40 \%$ dos casos. A maior parte dos pacientes era portadora de tumor periampular (66\%). O procedimento cirúrgico mais realizado foi a operação de Kausch-Whipple (70\%). Em seis pacientes (12\%) houve necessidade de ressecção de segmento do eixo mesentericoportal. O tempo cirúrgico médio foi 445, 1 minutos. Vinte e dois pacientes (44\%) evoluíram sem nenhuma complicação clínica e tiveram tempo médio de internação de 10,3 dias. As complicações mais frequentes foram: fístula pancreática (56\%), retardo do esvaziamento gástrico (17,1\%) e sangramento (16\%). Conclusão: nas últimas três décadas a ressecção pancreática ainda é considerada um desafio, principalmente fora dos grandes centros especializados. Apesar disso, com uma equipe habituada com esse procedimento, um baixo índice de mortalidade é possível.
\end{abstract}

Descritores: Pâncreas. Procedimentos Cirúrgicos Operatórios. Pancreatectomia. Pancreaticoduodenectomia. Mortalidade.

\section{REFERENCES}

1. Crile G Jr. The advantages of bypass operations over radical pancreaticoduodenectomy in the treatment of pancreatic cancer. Surg Gynecol Obstet. 1970;130(6):1049-53.

2. Cameron JL, Riall TS, Coleman J, Belcher KA. One thousand consecutive pancreaticoduodenectomies. Ann Surg. 2006;244(1):10-5.

3. Lillemoe KD, Rikkers LF. Pancreaticoduodenectomy: the golden era. Ann Surg. 2006;244(1):16-7.
4. Amico EC, Alves JR, João SA, Guimarães PLFC, Barreto EJSS, Barreto LSS, et al. Complicações após pancreatectomias: estudo prospective após as novas classificações GIEDFP e GIECP. ABCD, arq bras cir dig. 2013;26(3):213-8.

5. Bassi C, Dervenis C, Butturini G, Fingerhut A, Yeo C, Izbicki J, et al. Postoperative pancreatic fistula: an international study group (ISGPF) definition. Surgery. 2005;138(1):8-13.

6. Wente MN, Bassi C, Dervenis C, Fingerhut A, Gouma DJ, Izbicki JR, et al. Delayed gastric emptying (DGE) after pancreatic surgery: a suggested definition by the International Study Group of Pancreatic Surgery (ISGPS). Surgery. 2007;142(5):761-8. 
7. Wente MN, Veit JA, Bassi C, Dervenis C, Fingerhut A, Gouma DJ et al. Postpancreatectomy hemorrhage (PPH): an International Study Group of Pancreatic Surgery (ISGPS) definition. Surgery. 2007;142(1):20-5

8. Berberat PO, Ingold H, Gulbinas A, Kleeff J, Müller MW, Gutt C, et al. Fast track-different implications in pancreatic surgery. J Gastrointest Surg. 2007;11(7):880-7.

9. Gestic MA, Callejas-Neto F, Chaim EA, Utrini MP, Cazzo E, Pareja $J C$. Surgical treatment of chronic pancreatitis using Frey's procedure: a Brazilian 16-year single-centre experience. HPB. 2011;13(4):263-71.

10. Mali Júnior J, Carvalho GSS, Dias JA, Albagli RO. Emprego da anastomose pancreatojejunal tipo ducto-mucosa sem cateter transanastomótico em pâncreas de consistência mole e ducto fino: experiência inicial do Instituto Nacional do Câncer. Rev Col Bras Cir. 2007;34(4):218-21.

11. Perini MV, Montagnini AL, Jukemura J, Penteado S, Abdo EE, Patzina $R$, et al. Clinical and pathologic prognostic factors for curative resection for pancreatic cancer. HPB. 2008;10(5):35662.

12. Rasslan S, Casaroli AA, Abrantes WL, Mantovani M, Gasparini Neto S, Souza HP, et al. Pancreatectomia distal no trauma: estudo multicêntrico. Rev Col Bras Cir. 1998;25(6):409-14

13. Rocha LCG, Queiroz FL, Magalhães EA, Santos FAV, Caldeira DAM, Ribas MA. Duodenopancreatectomia: avaliação dos resultados em 41 pacientes. Rev Col Bras Cir. 2006;33(6):387-92.

14. Torres OJM, Barbosa ES, Barros NDC, Barros CA, Ferreira EDZ, Pereira HC. Duodenopancreatectomia: análise de 39 pacientes. Rev Col Bras Cir. 2007;34(1):21-4.

15. Machado MAC, Surjan RCT, Goldman SM, Ardengh JC, Makdissi FF. Pancreatectomia laparoscópica. Da enucleação à duodenopancreatectomia: 11 anos de experiência. Arq Gastroenterol. 2013;50(3):214-8.

16. Fontes PRO, Waechter FL, Nectoux M, Sampaio JA, Teixeira UF, Pereira-Lima L. Low mortality rate in 97 consecutive pancreaticoduodenectomies: the experience of a group. Arq Gastroenterol. 2014;51(1):29-33.

17. Balcom JH 4th, Rattner DW, Warshaw AL, Chang Y, Fernandezdel Castillo C. Ten-year experience with 733 pancreatic resections: changing indications, older patients, and decreasing length of hospitalization. Arch Surg. 2001;136(4):391-8.

18. Luft HS, Bunker JP, Enthoven AC. Should operations be regionalized? The empirical relation between surgical volume and mortality. N Engl J Med. 1979;301(25):1364-9.

19. Birkmeyer JD, Siewers AE, Finlayson EV, Stukel TA, Lucas FL, Batista I, et al. Hospital volume and surgical mortality in the United States. N Engl J Med. 2002;346(15):1128-37.

20. Birkmeyer JD, Stukel TA, Siewers AE, Goodney PP, Wennberg DE, Lucas FL. Surgeon volume and operative mortality in the United States. N Engl J Med. 2003;349(22):2117-27.

21. Tseng JF, Pisters PW, Lee JE, Wang H, Gomez HF, Sun CC, et al. The learning curve in pancreatic surgery. Surgery. 2007;141(5):694701.
22. Raval MV, Bilimoria KY, Talamonti MS. Quality improvement for pancreatic cancer care: is regionalization a feasible and effective mechanism? Surg Oncol Clin N Am. 2010;19(2):371-90.

23. Balzano G, Zerbi A, Braga M, Rocchetti S, Beneduce AA, Di Carlo $\checkmark$. Fast-track recovery programme after pancreaticoduodenectomy reduces delayed gastric emptying. Br J Surg. 2008;95(11):1387-93.

24. di Sebastiano P, Festa L, De Bonis A, Ciuffreda A, Valvano MR, Andriulli $A$, et al. A modified fast-track program for pancreatic surgery: a prospective single-center experience. Langenbecks Arch Surg. 2011;396(3):345-51

25. Lassen K, Coolsen MM, Slim K, Carli F, de Aguilar-Nascimento JE, Schäfer $M$, et al. Guidelines for perioperative care for pancreaticoduodenectomy: Enhanced Recovery After Surgery (ERAS®) Society recommendations. World J Surg. 2013;37(2):24058.

26. Lobo DN, Bostock KA, Neal KR, Perkins AC, Rowlands BJ, Allison SP. Effect of salt and water balance on recovery of gastrointestinal function after elective colonic resection: a randomised controlled trial. Lancet. 2002;359(9320):1812-8.

27. Grant FM, Protic M, Gonen M, Allen P, Brennan MF. Intraoperative fluid management and complications following pancreatectomy. J Surg Oncol. 2013;107(5):529-35.

28. Adham M, Chopin-Laly X, Lepilliez V, Gincul R, Valette PJ, Ponchon $T$. Pancreatic resection: drain or no drain? Surgery. 2013;154(5):1069-77.

29. Bassi C, Molinari E, Malleo G, Crippa S, Butturini G, Salvia R, et al. Early versus late drain removal after standard pancreatic resections: results of a prospective randomized trial. Ann Surg. 2010;252(2):207-14

30. Conlon KC, Labow D, Leung D, Smith A, Jarnagin W, Coit DG, et al. Prospective randomized clinical trial of the value of intraperitoneal drainage after pancreatic resection. Ann Surg. 2001;234(4):487-93; discussion 493-4.

31. Van Buren G 2nd, Bloomston M, Hughes SJ, Winter J, Behrman SW, Zyromski NJ, et al. A randomized prospective multicenter tria of pancreaticoduodenectomy with and without routine intraperitoneal drainage. Ann Surg. 2014;259(4):605-12.

32. Pratt WB, Maithel SK, Vanounou T, Huang ZS, Callery MP, Vollmer CM Jr. Clinical and economic validation of the International Study Group of Pancreatic Fistula (ISGPF) Classification scheme. Ann Surg. 2007;245(3):443-51.

Received: 03/04/2015

Accepted for publication: 13/10/2015

Conflict of interest: none.

Funding source: none.

Address correspondence to:

Enio Campos Amico

E-mail: ecamic@uol.com.br 